\title{
VARIATIONS OF THE ITALIAN GLACIERS IN I96I
}

\author{
By Manfredo Vanni \\ (Comitato Glaciologico Italiano, Torino, Italy)
}

DURING the summer of I96 I the annual glaciological studies in the Italian Alps, organized by the Comitato Glaciologico Italiano, were carried out at regular intervals.

In Table I are listed the 106 glaciers investigated: I 8 in the West Alps, 82 in the Central Alps and 6 in the East Alps. 63 of these glaciers were found to be retreating, i i were advancing, Io were stationary and 22 were so snow-covered that no measurements were possible (Table II). From the data in Table I it is clear that retreat is still predominant in the Alpine glaciers; this is not only evident from variations of the glacier snouts but also from other factors checked by the individual investigators. Among these observations the most interesting one is the separation of the ice tongues, which, when they become detached from the main glacier, become dead ice covered by an abundance of detritus. In the course of a few years this dead ice is bound to disappear, uncovering a stretch of valley plain sprinkled with morainic detritus not arranged in regular terminal moraines. As early as I94I this phenomenon was noticed on the Ghiacciaio del Lys in the Monte Rosa. In the course of one year the snout of this glacier wrinkled up for several hundred metres up-glacier, as far as the edge of a valley plain step roo $\mathrm{m}$. higher.

In I96I many glaciological investigators observed that this phenomenon, which had already commenced some years ago, was now complete for many glaciers; for instance, the Ghiacciaio di Gliairetta-Vaudet in the Gran Paradiso, the Ghiacciaio di Prè de Bar of Mont Blanc and the Ghiacciaio di Tza de Tzan in the Valpelline (the Dent d'Hérens group). Furthermore, the Ghiacciaio di Careser in the West Alps is tending towards a similar shortening process. The glaciers are withdrawing towards the high valleys.

The basins of alimentation no longer feed the ice tongues as much as formerly and hence the limit of the permanent snow is continually rising. Therefore, glacial retreat is still more intense, but there are other symptoms which lead the observer to believe that the retreat phase has reached its maximum, that the cycle is nearing completion and that a new advance is about to commence. The investigators have noticed among other things that in some high valleys or on high north-facing walls, where there used to be a small glacier which has disappeared in the last ten years, the residual snow is becoming thicker and lasts throughout the summer.

As an example, this phenomenon has been noticed on the north-facing wall of the Gran Sometta peak, in the Conca del Breuil in Valtournanche. Until r93o there was a small glacier on this north-facing wall, and this is shown in the list of the Italian glaciers drawn up by Porro in 1925 . This glacier completely disappeared after i930, but in the past two or three years there has been evidence of it reforming. Patches of residual snow lasted throughout the summers of 1959 and 1960 , but in 196 I they were wider, more compact and very thick, having the appearance of glacier-snow; namely, a deposit of snow having both the characteristics of ice-snow and of a glacier, i.e. crevasses indicating movement of the ice mass.

Also, checks for variations in the Maritime Alps show a general advance in the snouts of the 6 north-facing glaciers. There are also numerous snow-covered and stationary glaciers; those in the advancing phase represent about 10 per cent against 4 per cent in $195^{8}$ and $4 \cdot 5$ per cent in 1959. The stationary, the uncertain and the snow-covered glaciers numbered $3^{2}$ out of the 106 glaciers examined, whilst in $195^{8}$ they numbered only 12 out of 125 glaciers. In 196 i the glaciers in retreat numbered 63 out of 106 , in $195^{8}$ there were 108 out of I $_{25}$, and in 1959 there were 90 (representing 80 per cent) out of i 25 . 
Table I. Variations of the Italian Glaciers in I96I, COMPARED WITH I959 AND 1960

(Measurements in $\mathrm{m}$.)

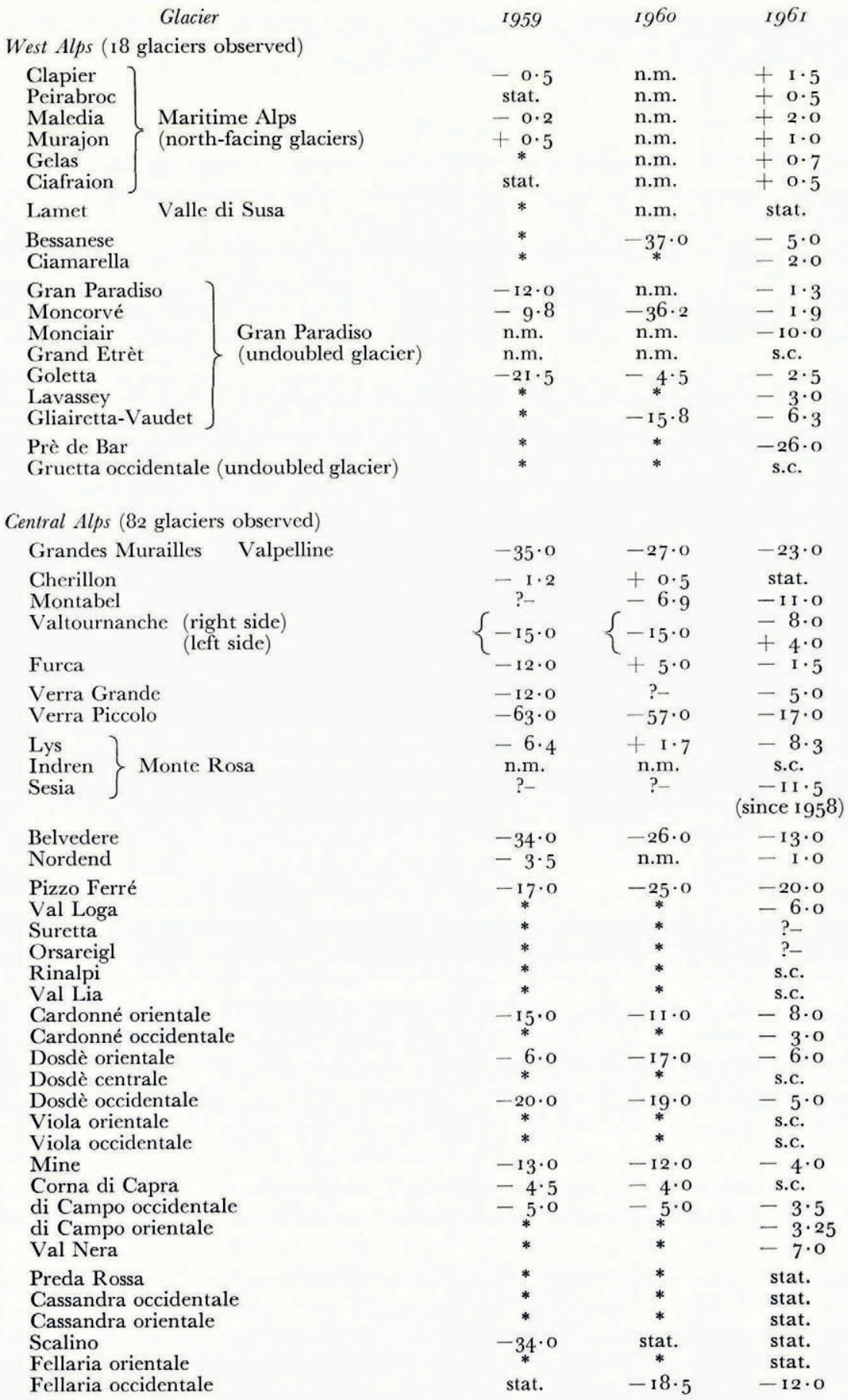




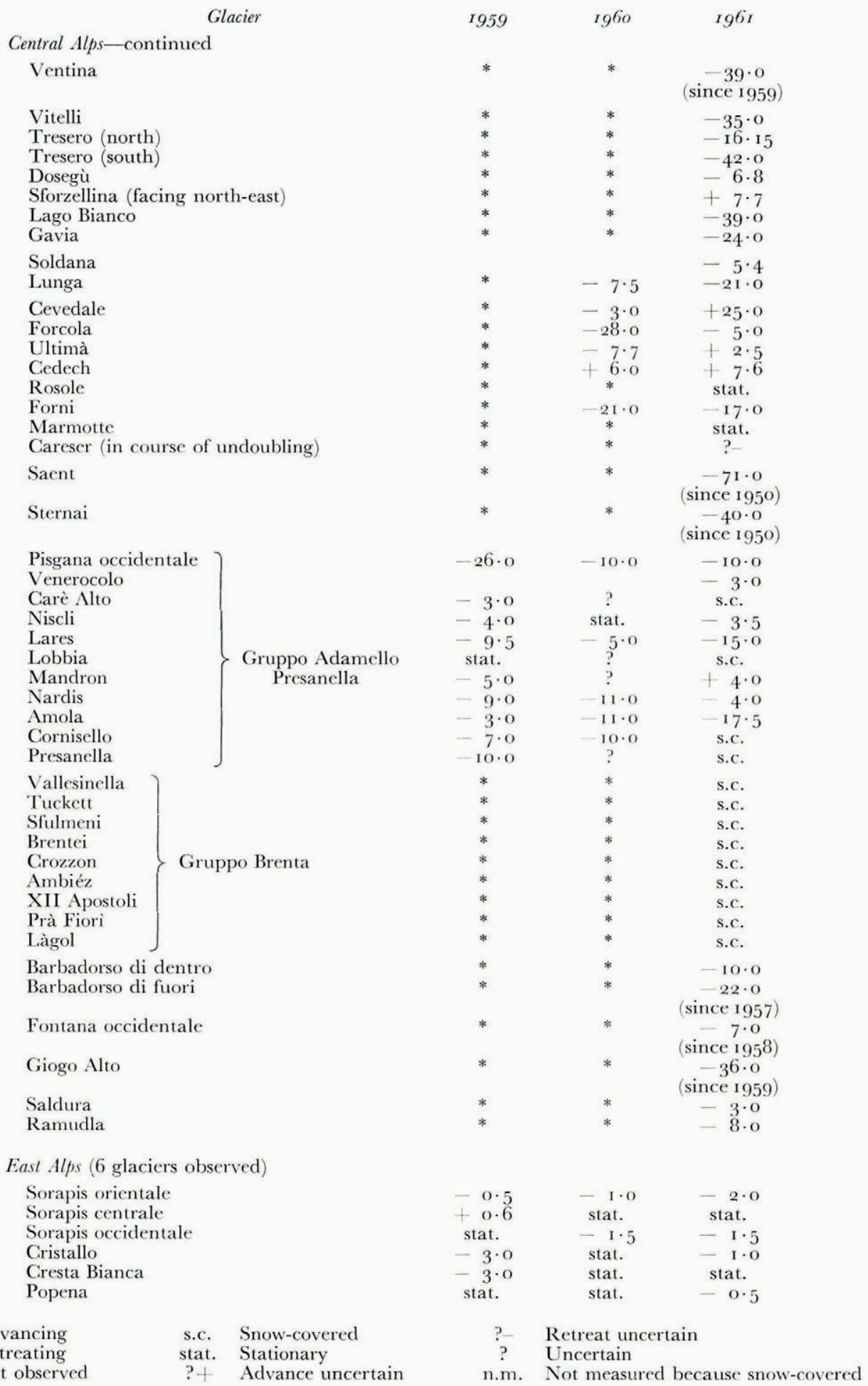


It is therefore not out of the question that certain symptoms could point to an early reappearance of our glaciers, since many years ago Monterin in his studies on variations of the Italian glaciers observed that the advancing phases and those of retreat do not occur simultaneously in the whole Alpine chain, but they begin in the Maritime Alps and proceed towards the Central and the East Alps.

Table II. State of Glaciers in West, Central and East Alps

$\begin{array}{lrrrr}\text { Glaciers in retreat } & 9 & 50 & 4 & 63 \\ \text { Stationary glaciers } & 1 & 7 & 2 & \text { 10 } \\ \begin{array}{l}\text { Glaciers in advance } \\ \begin{array}{l}\text { Snow-covered and } \\ \text { uncertain glaciers }\end{array}\end{array} & 6 & 5 & - & \text { I I } \\ \text { ToTAL } & 2 & 20 & - & 22 \\ & \text { I8 } & 82 & 6 & 106\end{array}$

In short, it may be thought that the retreat phase, having reached its maximum, shows a tendency to linger on while a new phase of advance is beginning. The years to come will either confirm this hypothesis or prove that it is only a transient phenomenon due to variation in the summer mean temperatures, which in the past years seem to have decreased. The effects of this have been specially examined in the watersheds which are less exposed to the sun. All this is in accord with the observations reported by Renaud (I96I) on variations of the Swiss glaciers in $1959^{-60}$.

MS. received ${ }_{15}$ February ${ }_{1962}$

\section{REFERENCE}

Renaud, A. r961. Les variations des glaciers suisses 1959-1960. Les Alpes. Revue du Club Alpin Suisse, 37 ${ }^{\mathrm{e}}$ An., 3 Trimestre, p. 106-12, 213-24. 